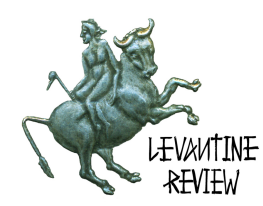

\title{
Jihad in Memory and History
}

\begin{abstract}
Abdelwahab Hechiche*
Writing in 1997, Emad Eldin Shahin, after considering the choice of the countries of the Maghreb as particularly significant, he also regretted the fact that "the politics of the Islamic movements in the Maghreb has been woefully neglected by the English-speaking academia." ${ }^{1}$ The choice of such a thorny theme ${ }^{2}$ has become all the more controversial now that Muslim and non-Muslim scholars and laymen have begun to wonder if there is One Islam or many Islams. For Marc Gaborieau,

Behind an apparent unity of beliefs and rites, the Muslim world is deeply fragmented on both the theological and cultural plans. Since its early stages, Islam has been marked by various sects, schools of thought (meaning jurisprudence) which propose competing visions of the relationship between the world, religion, doctrines, and practices. [...] Islamist movements would like to re-create the unity of the community of the believers but the new Muslim communities, in particular in Europe and the US, stress the religious and cultural diversification of the Muslim world. ${ }^{3}$
\end{abstract}

A parallel question had been raised about "terrorism or terrorisms":

Terrorisms: in plural, because they are multidimensional in their manifestations, in their intensity, in their history. Meanwhile, this plural is more modest than the singular, because it would imply that we are dealing with the question under all its aspects, from the perspective of one central concept and on the basis of a logic which would decline the totality of its elements. ${ }^{4}$

${ }^{1}$ Emad Eldin Shahin, Political Ascent: Contemporary Islamic Movements in North Africa, Westview, 1997, p. 4.

${ }^{2}$ Some important ideas in this paper were used for the 2010 Oxford Round Table on

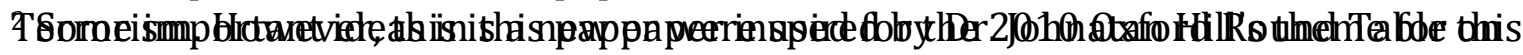
Terrorism. However, this is a new paper inspired by Dr. Johnatan Hill's theme for this seminar. The two concepts of "Event" and "Idea" led me to devote several months of new and enlightening research.

3 Marc Gaborieau, "Les Islams," in Questions Internationales, no. 21-septembre 2006, 6.

4 Editorial, Les Terrorismes, in Questions Internationales, no.8-juillet-aout 2004. 


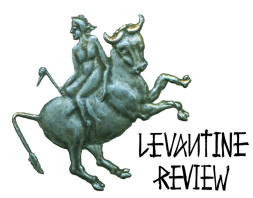

For Nadine Picaudou, "These multiple Islams of contestation of protest, surging against foreign dominations which threaten the social order while creating obstacles to emerging national aspirations, contribute to the forging of modern discourse of jihad and help the evolution of the ancient meaning of legal war towards a just war."

The twilight of the twentieth Century was marked by a strange paradox: The rise of religious fanaticism in parallel with some of the greatest human achievements in terms of liberation from colonialism and authoritarianism. The paradox may even be more striking when one remembers that religion has played a major role in liberation theology in Central and Eastern Europe as well as in Latin America. For Milton R. Kronvitz, the terms "religion" and "religious" appear in the US Constitution without being defined. Yet beginning with cases involving the Mormon Church in 1875, the US Supreme Court never missed a chance to stress the separation of Church and State. This was seen again, most recently, in the Alabama case where a Judge was forced to remove a statue with the inscription of the Ten Commandments. In 1961, the Supreme Court considered the provision of the Maryland Constitution that required a declaration of belief in God for public office. Unanimously, the Court declared that such a requirement was an invasion of freedom of religion and a violation of the First Amendment. ${ }^{6}$ Speaking for the Court, Justice Black said: "We repeat and again reaffirm that neither a state nor the Federal government can constitutionally force a person to profess a belief or disbelief in any religion."

Today, in 2015, both Western European and U.S. laws seem to be more and more challenged from within and from without, especially, due to the growing legal-religious claims by militant Islamic groups whose presence has drastically changed the demography of non-Muslim host states. ${ }^{8}$ Samuel Krislov argued that "The fundamental difficulty in arriving at a stable balance is quite simply that state and religion have unstable

${ }^{5}$ Nadine Picaudou, L'Islam entre religion et ideologie, nerf essais. Gallimard, Paris, 2010, 212.

${ }^{6}$ Milton Kronwitz, "The Problem of Constitutional Definition of Religion," in Religion and the State: Essays in honor of Leo Pfeffer; edited by James E. Wood, Baylor University Press, Waco, Texas, Davis Vs Beason, 133US 333 (1890), p. 47, quoted by A. Hechiche, Religion, Politics, and Mediation in North Africa: Tunisia, in Loccum: Politik mit der Religion, 65-99, 2001

7Ibid.

${ }^{8}$ A critical controversy emerged in G.B in May-June, 2014 about the degree of freedom in Islamic education. It appeared in Birmingham City Council with an anonymous document called Operation Trojan Horse. See Stephen Castes and Kimiko De Freytas-Tamura, Rift Deepens in Britain over Claims of School Infiltration Plot by Islamic Extremists, The New York Times, June 9, 2014, p. A4, and Stephen Castes, Britain School Report Cites Division over Islam, The New York Times, June 10, 2014, A5. 


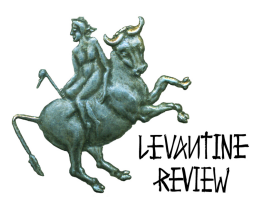

boundaries. ${ }^{9}$ More explicitly, Krislov adds: "Those religions that operate in states that fuse politics and moral force still have predominantly some separate structure for differing elements and subsequent rivalries. Those states that attempt to separate the two domains, find demarcation less than complete. God and Caesar do not normally conveniently limit their claims upon the individuals involved." 10 Such an ambiguity was made more pertinent with Pope Jean Paul II's visit to Poland in 1983, dramatically underscoring the message that what is a religious duty and need for one entity, may emerge as emphatically political to another.

This issue of separation becomes thornier and more critical for some religions that are supposed to be political, intrinsically political. Muslim states fall under such a category, all the more as the essence of the idea of separation of state and church has been generally perceived as an imported concept from the West. For Bernard Lewis, the three monotheistic religions are significantly different in their relations with the state and their attitudes toward political power. Comparatively speaking, according to Bernard Lewis: "...Islam, from the lifetime of its founder was the state, and the identity of religion and government is indelibly stamped on the memories and awareness of the faithful from their own sacred writings, history, and expression..."11

\section{Part I \\ Islam and the West: Between Cooperation and Confrontation}

\section{Political Islam and Terrorism}

Another striking paradox is to be found in the year 1979 or 1400 in the Islamic era. That year, a glamorous festival was planned as an expression of the Islamic Renaissance to coincide with the new Islamic Century. The same year was marked by the US hostage crisis in Teheran, and the Islamic Revolution. Obviously, like the word "aggression," terrorism has become one of the most controversial terms in modern International Relations. Although a cliché, the opposition between a "terrorist" and a "freedom fighter" became a fixture in ideological debates from the classroom to the United Nations. When President Bill Clinton's Administration was still uncertain about its foreign policy options in the Balkans, or even in the Mediterranean with regard to the bloody Algerian fratricide, the choice that emerged was for a pragmatic, even conciliatory approach to the Islamic ferment. This choice was made explicitly in a speech by Anthony Lake, then the National Security Council's Advisor: "We reject the notion that a renewed emphasis on traditional

${ }^{9}$ Samuel Krislove, "Alternatives to Separation of Church and State in Countries Outside the US," in Religion and the State, 42.

10 Ibid. p.422

11 Bernard Lewis, "The Return of Islam," in Religion and Politics in the Middle East; edited by Michael Curtis (New York: West View Press), 1981, 11-12. 


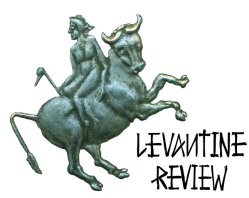

values in the Islamic World must inevitably conflict with the West or with democratic principles."12 For Mr. Lake, any clash would be between oppression and repressive governments, between isolation and openness, between moderation and extremism. The essence of that speech was that the issue was not Islam but Muslim radicals who wanted to use religion to cover their intentions, the naked pursuit of political power. ${ }^{13}$

Bruno Etienne lamented over the quasi sarcastic response of certain "scientific" circles to his team's initiative in choosing 1979/1400 Hijra year for a systematic study of Islam in the world, and especially in France. Yet, since then all major universities and research centers have created highly specialized units for the study of terrorism. To paraphrase Marx, the problématique of this phenomenon has been amplified by the fact that "Neither researchers nor the faithful (the Muslims) know the history they are making. In a slightly different manner, the history they narrate is not the one they make, but all need to say it in order to make it."14

In recent times, one of the major turning points revealing or seeming to reveal an intrinsic association between Islam and political violence was certainly the Salman Rushdie Affair, when the British author was condemned to death by a fatwa issued by Imam Khomeini for what was perceived as a "blasphemy" in Rushdie's book, The Satanic Verses. The shock was so great that in France the media called "Descartes and Voltaire for Help!" or asked Mohammed "to wake up, because his followers had become insane." People were wondering whether "Islam emanated from Holy War."15 Hervé Bleuchot and other Western scholars tried to contextualize the Salman Rushdie Affair by saying that "a social reaction" must be deeply rooted in history with a certain degree of influence on related legislations. Thus, it becomes imperative to study Islam as it is, as a vehicle of potential actions or acts that disturb the public order instead of only focusing on the delinquency of some Muslims.

But Hervé Bleuchot warns us not to fall into the other illusion:

Religion is nothing but a certain form of the ideological factor and this factor is far from having a decisive impact on crime. [...] In addition, the ideology of Muslims in France, including the Islamists, is complex, ambiguous, not at all homogeneous. It is penetrated, often unconsciously, by psychological values and reactions which are less

\footnotetext{
12 Anthony Lake, quoted in "Live and Let Live, America Takes a Pragmatic Attitude Toward Islamic Rise," Asia Week, June 8, 1994, 22.

13 Ibid.

14 Etienne Bruno, "Introduction: L' Islam en France: Islam, Etat et Société," Annuaire de l'Afrique du Nord, 1988, Editions CNRS, 3-391.

15 Hervé Bleuchot, "La Grand'Peur de l'Islam: Mythes et Réalités." "Ce qui est dangereux dans l'Islam," Annuaire de l'Afrique du Nord, Editions CNRS, 1988, 193.
} 


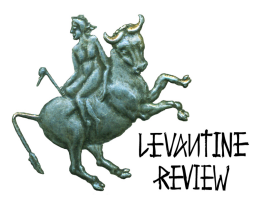

related to normal Islam than an Islam in abnormal situation: Islam in hardship situation (Mihna) or in Islam in exile (hijra). ${ }^{16}$

According to this author, the most fervent Muslims, the most militant, experience intense psychological conflicts, due to their double marginality, within French society and in their relationship with ordinary Muslims. This could be corroborated by the most recent growing cases of US Muslims turning terrorists: Major Hassan at Fort Hood in the fall of 2009 and a few new young Muslim citizens arrested between January and April 2010. ${ }^{17}$ The brutal and inhuman beheading of two Western journalists by ISIS has been one of the main items of the NATO meeting in Wales, UK, on Septmeber 3-4, 2014.

Existentially speaking, such a dilemma for transplanted or localized Muslim communities lead to the problématique of the relationship between Reason and Faith which is not much different from Pope John Paul II's encyclical Ratio et Fides. Mohammed Arkoun dealt with it eloquently: "The claim that an eternal Reason in pre-established harmony with a revealed teaching, has always been present in different schools of Islam, but also in Judaism and in Christianity." 18 It is important to notice that M. Arkoun questions the view of Muslims who see "a superior reason" to all others which functioned or still functions out of any reference to God's Word in the Quran. For this reason, M. Arkoun offers two suggestions:

From a general historical perspective, it is urgent to apply to the study of Islam, new methodologies and problématiques, in order to correct the gaps and dangers of linear and abstract history of ideas. Current political Islam claims to belong to an order of reasons that

16 Bleuchot quotes Dhaoud Zouhair;s article: “Islamistes en Hijra absolue: D’un Islam transplanté à un Islam transformé?, in Peuples Méditerranéens, avril-septembre 1985, pp. 111-124.

17 The New York Times, Path from Troubled Teenagers to Terror Suspects, Saturday June 12, 2010, pp. 1 and A16. See also "The Terrorist Next Door" by Michael A. Sheehan, The New York Times, May 4, 2010, p. A25, and an article by Virginie Malingre "Un think tank britannique dresse le portrait-robot du terrroriste islamiste type au Royaume -Uni" in tle Monde, Paris, Jeudi 8 juillet, 2010, 6. But this problem has not been limited to Europe. More and more citizens of Canada and the US began to appear in Syria. See Kimiko De Freytas-Tamura, Foreign Jihadists Fighting in Syria Pose Risk to West. 70 siad to be from US. Qaeda Group hope to prepare recruits to sgtrike back home, The New York Times, May 30, 2014, p. 1 and p. 12. According to Euro-Islam, May 23, 2014, on April 23, the French government unveiled a dozen of proposals at limiting the number of French citizens traveling to Syria...It was estimated that 500 of them had joined the fighting. http://www.euro-islam-info/2014/05/23/french-jihadism-in syria-cyberindoctrination/?utm...5/28/2014 ${ }^{18}$ Mohammed Arkou, "Le Concept de Raison Islamique," Annuaire de l'Afrique du Nord, CNRS, Paris, vol. 1979, 305. 


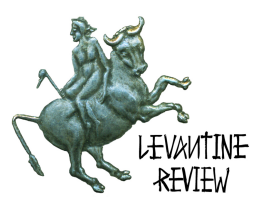

is associated with the legitimizing function of classical Islamic reason. The consequence is the imperative duty of questioning the religious, historical, and philosophical pertinence of such a pretense.

\section{A. Time between Sacred Memory and Profane History}

In asking whether Time is par excellence lived before being the object of speculation, François Chenet considers that it is imperative to begin with a description of the various ways we live time before trying to grasp the experience of time at various levels. For Chenet, we apprehend it at two opposite levels: An existential one and an operative one. ${ }^{19} \mathrm{~A}$ Muslim Hadith tells us that Prophet Mohammed advised his followers: "Live as if you were to die tomorrow, and act as if you were to live forever." One time is for moral and ethical life, the other is for action and planning, which seems to correspond to Chenet's notion of "operational time." "Lived or experienced, time is that form of temporality proper to the life of consciousness; and because of its temporal structure, consciousness is submitted to the law of succession." 20 This analysis is corroborated by F. Ravaisson: "Since there is nothing in the distinct consciousness but under the general law of movement, and since movement is in time, the condition, the being of consciousness is in time. Time is the first law and necessary form of consciousness. Everything that is in consciousness is therefore a change whose duration is in a subject that is lasting and does not change."21

Time in history or time of history is associated with the life of societies, of civilizations, and cultures. This is why and how "Time emerges out of social life from which it cannot be separated. [...] Time not only informs social reality, but, in particular, it constitutes a major social link [...] to the extent that social organization of time allows people to have a point of reference and to act collectively." 22

Dealing directly with Event and Perception, Krzysztof Pomian adds: "Whatever our efforts, we remain incapable of apprehending everything that happens around us. Thus, we choose uncertainty. This is why every set of units (events) we have recorded is nothing but a subset of units of what had actually happened."23 For K. Pomian, the first corollary of the identification of any event to the perceived change is that any event always presupposes a spectator, or to use Merleau-Ponty's words, that "There are no events without someone affected by them and whose complete perspective justifies their individuality." ${ }^{24}$ However,

${ }^{19}$ Chenet, François, Le Temps, Temps Cosmique, Temps Vécu, Armand Colin, Paris, 2000, Introduction, 7

${ }^{20}$ Chenet, Le Temps, Temps Vécu..., p. 9

${ }^{21}$ Ravaison, F, quoted by Chenet, in Le Temps..., 9.

22 Chenet, 148.

${ }^{23}$ Pomian, Krzysztof , L'Ordre du Temps, Editions Gallimard, 1984, 16.

${ }^{24}$ Merleau-Ponty, Phénoménology de la Perception, Paris, Gallimard, 1945, p. 470, quoted by K. Pomina, L'Ordre du Temps, note 1, 17. 


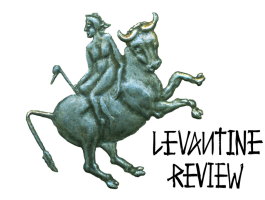

far from resolving all the questions, K. Pomian adds: "For an event to happen, it is necessary that a change take place in the world, and that it be accessible to a plurality of virtual spectators, capable of a mutual exchange of their respective perceptions." 25 For K. Pomian, Herodotus's established authority as the founder of history may be questioned by someone who would ask:" What entitles you to speak about events you have not witnessed?" 26 Such a legitimate question may be equally pertinent for a Muslim who would like to balance his own faith with his search for the truth with regard to the original meaning and use of Jihad. Bassam Tibi did struggle with the same dilemma. After referring to Habermas's view that post-modernism might well be presented as a falling back into conditions of pre-modernity, Bassam Tibi projects his own existential identity debate:

Being myself a non-European as well as a Muslim, I feel free to criticize the politicization of religion and also to depict political Islam as a cultural variety of neoabsolutism. [...] I view Islamism as the Islamic variety of religious fundamentalism. In contrast to this political ideology, Islam is a religious and cultural system, not a neoabsolutism. In my own case, it is a reference of my identity. [...] The commitment to cultural modernity by a Muslim is not cultural treason [....] rather it stands in the tradition of Islamic rationalism. ${ }^{27}$

In their exhaustive book, Peter Claus and John Marriott explain how "Pre-industrial societies or pre-literate societies had no such idea of time running either forward or backward. Without an agreed method of measuring and keeping time, these societies could not conceive of "eras," "ages," or "periods" [...] as there was no established chronology, there could be no agreed calendar." ${ }^{28}$ It is quite interesting to notice that in the holy book of Islam, we can read references to major events "historically associated with "years of" spectacular roles of animals, insects, or natural weather events. These two authors give more authority to this idea of a-temporality with a reference to Pierre Bourdieu's observation of the Kabyle Berbers in Algeria: "Events in the past are located by reference to memorable occurrences: One speaks of the year in which there was misery, the year in which there was the plague..." 29 But one can still ask how did the cyclical notion of "year"

25 Ibid. 18.

26 Ibid. 19.

27 Bassam Tibi, From Religious Belief to Political Commitment: The Fundamentalist Revolt Against the secular Order: Between Cultural Modernity and Neo-Absolutism, Chapter 6, in Islam: between Culture and politics, $2^{\text {nd }}$ edition, Palgrave, Macmillan, 2005, pp. 132-133. ${ }^{28}$ Claus, Peter, and Marriott, John, The Order of Time: Time, History, Modernity, in History, an introduction to theory, method, and practice, London, New York, 2012, p. 27.

${ }^{29}$ Bourdieu, Pierre, The Attitudes of the Algerian Peasants towards Time, J. Pitt Rivers (ed.) Mediterranean Countrymen: Essays on the Social Anthropolofy of the Mediterranean Paris: Mouton XXX pp. 55-72, quoted by Peter Claus and John Marriott, in History, an introduction...p. 59. 


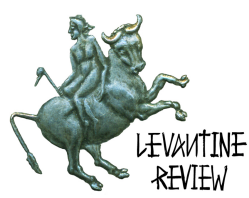

enter people's consciousness? Pierre Bourdieu warns us "To avoid seeing here points of division, which would pre-suppose the notion of regular measured intervals, that is to say a special conception of the temporal. The islands of time which are defined by these landmarks are not apprehended as segments of a continuous line, but rather as so many self-enclosed units." 30 Is this a vista for the specificity of Islamic Time, or for time in Islam?

B. Islamic Time in History

One may ask if it is possible to apply the merging so-called scientific notions inherited from Herodotus and Thucydides to Islamic perception and interpretation of history (Tarikh)? For modern specialists of the "History of History," it is imperative for the historian not to judge the past, nor to instruct his contemporaries but simply to give an account of what really has happened. ${ }^{31}$ Here begins the dialectical issue between history and belief most eloquently dissected by Tarif Khaldi who, trying to distinguish the apprehension of time by Judaism and Christianity on one hand, and by Islam on the other hand, wrote:

The Quranic vision of history rests upon a certain conception of time and space and a certain style to express that conception. Islam and history are coeval: "It was God who called you Muslims from days of old" (Sura 22:78) ${ }^{32}$ [...] Thereafter, the Quran pans over a landscape where time is less a chronology than a continuum, where Abraham, Moses, Jesus, and Mohammed are all described in a grammatical tense which one is tempted to call the eternal present. The whole of history is present at once to God. Within this design, events are arranged in clusters repetitive in form. This means that a Quranic quissa or tale is closer in function and meaning to a "case in point" or "an affair," or even a "parable" than it is to a story or narrative. ${ }^{33}$

This notion of a permanent present may be compared to the English progressive form in conjugation.

30 Pierre Bourdieu, The Attitudes of Algerian Peasants, 59.

31 Leopold Von Ranke, The Secrets of World History: Selected Writings on the Art and Science of History (ed) and translator, Roger Wines, New York: Fordham University Press, 1981, quoted by Stephan Encel, Histoire et Religion: L'Impossible Dialogue, essais d'analyse comparative des grilles de lecture historique et monotheists in Chapitre I: Des Documents et des Hommes: La construction de l'Histoire, L'Harmattan, Paris, 2006, npn. 32 "And strive for Allah with the endeavor which is is His right. He hath chosen you and hath not laid upon you any hardship..." in The Meaning of the Glorious Koran: An Explanatory Translation by Marmeduke Pickthall, G.Allen \& Unwin, LTD, 1969, 347.

33 Tarif Khaldi, Arabic Historical Thought in the Classical Period, Cambridge University Press, 1994, 8. 


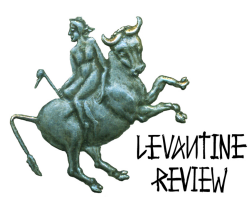

When referring to Ibn Khaldun, Khaldi corrects a misperception of scholars who considered Ibn Khaldun's History to be "an unworthy sequel of his celebrated Muqaddima. ${ }^{34}$ But while looking at the relationship between shari'a and siyasa,

Ibn Khaldun highlighted a dominant concern of the age: Relationship between power and virtue. [...] He argued that power was necessary, that it was in itself, neither good nor bad but a special kind of skill to be used badly or well in the maintenance of the state. Seen in their historical context, these views seem to emanate from reflections on government and justice adumbrated in the thought and writing of Ibn Khaldun, Turtushi, and Ibn Tiqtaqua. But Ibn Khaldun startles by both the consistency and the expansion of the vision. [...] The universe of Ibn Khaldun is a structured whole with its gradations of reality and meaning. History is the record of this structure and it too reflects the many permutations of siyasa, the levels in which the levels interact and develop. The Muqaddima sets out the broad outlines of this scheme; the history demonstrates how that scheme operated in time. Neither can be fully understood without the other and the relationship between them is frequently underlined by Ibn Khaldun. ${ }^{35}$

According to Khaldi, another critical point for today's understanding of the great and violent debate about Islamism - within the Muslim world and beyond-is Ibn Khaldun's "ubiquitous correctives":

In many instances the boldness of the criticism is accentuated by the sensitive nature of the opinions expressed. Ibn Khaldun was not only correcting historical reports but challenging the majority view of theologians, jurists and historians on a large number of controversial issues. In re-writing history, he knew full well that ancient opinions would need to be questioned; prejudices cast away, fabrications exposed. ${ }^{36}$

Returning to the grammatical nuances of the apprehension of time, Bowering adds:

The link of causality that appears to rule the world human life becomes subordinate to Allah, and natural causes give way to divine will. As a rule God does not interrupt the continuity of events [...] though He is able to intervene at any moment by what is commonly termed as a miracle. [...] Atomism was not only most congenial to a vision of

${ }^{34}$ Khaldi, Tarif, Historical Thought, 222.

35 Ibid. 224.

36 Ibid. 225.

ISSN: 2164-6678 


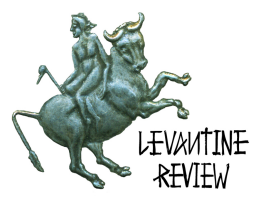

God acting instantaneously in the world as the sole true cause, it also proved most closely akin to Arabic grammar, which lacks genuine verbs for 'to be', and 'become'. ${ }^{37}$

However, one may respectfully question Bowering's assertion that "neither does Arabic employ the tenses of past, present, and future. Instead, it uses verbal aspects of complete and incomplete, marking the degree to which an action has been realized or is yet to be realized without distinguishing precisely between present and past." 38 Probably, the ultimate uniqueness of Islamic representation of time is to be found in Anne Marie Schimmel broad ranging works on Sufism when she returns to the concept of time that permeates the poetry of Jalal-al-Din ar-Rumi and other Persian mystics. ${ }^{39}$ According to Bowering,

One principal image of time that catches [Shcimmel's] eye is portrayed by various renderings of a non-canonical tradition, the hadith nabawi "I have time 'waqt' with God" in which Persian mystic poets perceive Mohammed's privilege of intimate communion with the eternal. [...] While Rumi was inspired by this tradition focusing on the Prophet's waqt, Ibn al-'Arabi was captivated by the canonical tradition of a hadith qudsi. "I am time (dahr), a majestic utterance of the eternal calling Himself dahr. ${ }^{40}$

In his book, Israelis and the Jewish Tradition: An Ancient People Debating Its Future, ${ }^{41}$ Rabbi David Hartman inspires me to suggest that in the Muslim World, we have a young Umma debating its past. This dichotomy may be supported by Chenet who sees "Time as constituting itself within the limits of the sacred, and making the form of the cyclical rituals," especially when Chenet opposes "cold societies" to "hot societies": "Whereas the West is recorded in the urgency of time and history [...] which is the memory of its flowing, there are cultures which let themselves be dissolved into eternity, not by nonchalance, but by lucidity: For these cultures, time is nothing else but the relative perception we have of the immutable." Levi Strauss himself denounced the illusion according to which archaic societies had stayed out of time-because all societies have a history. The so-called archaic cold societies are not stationary, but perhaps more conservative than our modern civilization, in the sense that they are more attached to a certain order and that they have

37 Guerard Bowering, The Concept of Time in Islam, Proceedings of the American Philosophical Society 141 (1), 55-72, quoted by Peter Clauss and John Marriott, History, an introduction, 28.

38 Ibid.

${ }^{39}$ Annemarie Schimmel, Mystical Dimensions of Islam, Chapel Hill, N.C, University of North Carolina Press, 1975, 220.

${ }^{40}$ Guerard Bowering, Ibn-al-'Arabi and his writings on Time, in Ibn al'Arabi's concept of Time, 108.

${ }^{41}$ David Hartman, Israelis and the Jewish Tradition: An Ancient People Debating its Future, Yale University Press, 2000. 


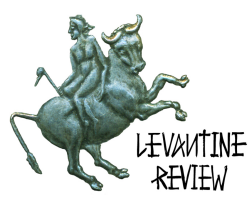

the proclivity to integrate events that keep them in the pre-existing system." 42 This is all the more pertinent to our approach to memory and history in the Islamic thought, as we can detect a critical contradiction between what Islam refers to as Jahiliya or the Age of darkness or ignorance in pre-Islamic time, and the pride espoused by Muslims regarding the transmission of Greek science and philosophy to the West.

\section{Part II Jihad between Peace and Terror}

\section{A Historical Perspective}

For Asma Afsaruddin, the scholarly literature from the first three centuries of Islam reveal that there were competing definitions of how best to strive in the path of God, engendered by the polyvalence of the term "Jihad." Recent rigorous research has established that "there was a clear divergence of opinion regarding the nature of Jihad and its imposition as a religious duty on the believer through the first century of Islam and into the second half of the second century." 43 We can already see that our search for the roots of the use of terror in Islam, and its use today in the name of Islam, requires two historical moments: Early classical Islam and modern Resurgence of Islam in the eighteenth and nineteenth centuries.

Naturally, it may be assumed that whereas the emergence of Western modernity goes back to the Renaissance, modernity in the Orient was to be under the impact of the West. ${ }^{44}$ But both moments seem to be exceptional circumstances when Islam or Muslim societies were or felt threatened from within and from without. During the first phase, Islam was already divided between Mecca and Damascus while both centers of power felt threatened by Byzantium. The second phase was marked by the victorious march of Christian Europe into Muslim lands from Napoleon's Egypt's Expedition to France's occupation of Algeria in $1830 .{ }^{45}$ Regarding the use of terrorism or armed struggle in cases of national liberation

42 Chenet, 148.

43 Afsaruddine, Asma, Views of Jihad Throughout History, in Religion Compass, 1/1 (2007) 165-169.

44 Groupe de recherches Islamo-Chrétien, Foi et Justice, Editions du Centurion, Paris, 1993, 77.

45 The carving of the Middle East in 1917 through the Sykes-Picot and the Balfour Declaration is being questioned today, in June-July 2014 by ISIS/ISIL. In his Journal, Maurice Hankley, Secretary of the British Government, wrote on December 1920: “...Lloyd George and Clemenceau were taken to the French embassy. When they were alone, Clemenceau said: :Well! What are we going to talk about?" "Of Mesopotamia and Palestine" answered Lloyd George. "Tell me what you want" Clemenceau asked. "I want Mosul" Lloyd George answered. "You will get it." Clemenceau said. "Anything else?" Clemenceau asked. "Yes! I also want Jerusalem." Lloyd George continued. "You'll get it.” Clemenceau said. See, 


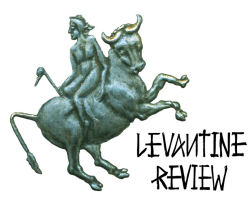

movements such as Algeria, B. Marie Perinbam offers us an eloquent analysis of Fanon's revolutionary thought. "Drawing on natural law, the Scriptures and English common law, [...] republicans such as Milton defended the "crime" of regicide in Tenure of Kings and Magistrates, and one only need be reminded that Locke's moral right of revolution preceded Marx's by over two hundred years." 46

The enemy of America is not our many Muslim friends; it is not our many Arab friends. Our enemy is a radical network of terrorists, and every government that supports them. We are not deceived by their pretense to piety. [...] They are imbued with the spirit of religion, these terrorists only claim to be. [...] The terrorists are defined by their hatreds: They hate democracy and tolerance and free expression and women and Jews and Christians and all Muslims who disagree with them. [...] Others killed in the name of racial purity, or the class struggle. These enemies kill in the name of a false religious purity perverting the faith they claim to hold. ${ }^{47}$

President G. W. Bush's comments above are not incorrect. Islam was being hijacked. Yet the terrorist attack of September 11, 2001 could also be considered as "an act out of consummate religious devotion"; "the performance of a sacrament; one intended to restore to the universe a moral order that had been corrupted by the enemies of Islam and their Muslim collaborators." 48

\section{A. Cultural and Religious Roots of Jihad}

How can we comprehend this type of extremism while any average Muslim is taught that, in its very essence, Islam is Peace? One of the best answers is to be found in the Honorable Judge Muhammad Said al-Ashmawy's multi-dimensional analysis of the roots of ArabIslamic use of terror and political assassination. He considers the Middle East as the theatre of Arab-Islamic terrorism with a malicious association and exploitation of the Palestine Question. Thus, Judge al-Ashmawy tackles the specificity of Middle Eastern terrorism by analyzing pre-Islamic Arab societies. His analysis underlines three factors:

To the tribal nature of pre-Islamic Arabia, he opposes the Quranic humanistic and the universal code of conduct: "O! Men! We created you from a male and from a female! We constituted you as peoples and tribes to get acquainted with one another..." For Judge al-

“Je veux Mossoul”, Henry Laurens, Le Monde Diplomatique, juillet 2014, 10, rubrique des archives.

46 Perinbam, B. Marie, Holy Violence: The Revolutionary Thought of Frantz Fanon, Three Continents Press, Washington, D.C, 1982, 108.

${ }^{47}$ President George W. Bush, State of the Union Address, January 2002, quoted by Daniel Benjamin and Steve Simon, in The Age of Sacred Terror, Random House, New York, 2002, 38-39

48 Benjamin, Daniel and Simon, Steve, The Age of Sacred Terror, 39. 


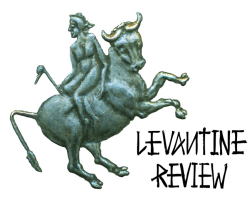

Ashmanwy, the Quranic humanistic influence on the Arabs was considerable during the life of the Prophet and his first two successors, Abu Bakr (632-634) and Omar (634-644).149 However, that period of time was too short to actually and deeply transform the nature and mentality of the new Muslims. Thus, around the end of the leadership of the Caliph Omar Ibn Khattab, tribal tendencies and characteristics resurged and influenced Islam. "Tribal characteristics got mixed with Islamic consciousness and the history of Islam was to be identified with inter-tribal struggles and feuds when the latter were covered with the masks of religion and shari'a."50

The second element was extremism. Throughout the pre-Islamic period, Arabs were known for their extremism in all their affairs. Compromise and conciliation were alien concepts to their culture and nature; hence Islam's condemnation of this negative aspect of the preIslamic Arab personality through a verse in the Quran denouncing extremism. ${ }^{51}$

The third factor was the "incessant fighting" among pre-Islamic Arabs:

During pre-Islamic times, courage was among the most significant virtues. The cause and the result of fighting were irrelevant. In such an unhealthy atmosphere, some individuals were outlaws, committing barbaric acts. They were called "sa'aliq" (outlaws, thieves, and beggars). Here again, Islam addressed such inhuman behavior by re-orienting the use of courage toward Djihad, making it a struggle against the self in order to reach the true faith. Islam also made this Djihad a collective effort for all the believers against aggression, with a total sacrifice of oneself and one's belongings for the sole victor of religion and moral values. ${ }^{52}$

This proclivity for violence, be it private or public, ${ }^{3}$ tribal, ethnic, or religious, is also to be found in three historic political assassinations that marked the early stages of Islam,

${ }^{49} \mathrm{Al}$-Ashmawy, Said Mohammed, Terreur et Terrorisme au Moyen-Orient, in Contre L'Intégrisme: Une Expérience Egyptienne, by Rfaat al-Said, Muhammad Said al-Ashmawy, and Khalil Abdel-Karim, Maisonneuve et Larose, Paris, 1994, 66-67.

50 Ibid. p. 67 "Thus We have appointed you a middle nation, that ye may be witness against mankind and that the messenger may be witness against you..." in The Meaning of the Glorious Koran, by Marmeduke Pickthall, 141.

51 Soura 2:143

52 A-Ashmaawy, Said Muhammed, 69.

53 With the irresistible emancipation of women in the Arab-Muslim world, feminism has begun to defend the right of sexual orientation as one of the fundamental rights of modern and positive International law. IN Holy Hatred, Anissa Helié corroborates Amnesty International investigations with her own experience of discrimination and persecution by asserting that "The State is not alone in practicing repression. Communities and families 


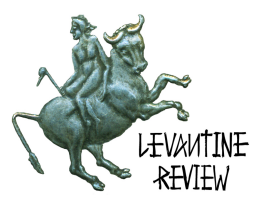

making them the quintessential roots of today's terrorism in the name of "Jihad fi Sabil Allah" (in the path of Allah,) or even worse, in the name of Allah Himself. ${ }^{54}$ Bassam Tibi disagreed with orientalists of the old school who seldom went "beyond the confines of textual philology" because "historical reality is not a text." In addition, using the authority of the social historian Reinhard Bendix who considered that classical Islam was based on "royal authority" - which is not the religion of Islam-Bassam Tibi also refutes the arguments of "reform-Muslims like Said Ashmawy." 55

\section{B. A Philological Approach}

For Nadine Picaudou, the term jihad, formed on the same verbal root of the term ijtihad, was used for the interpretations of texts to translate the general idea of an effort directed toward a determined goal, an effort against oneself, and, at the same time, an effort in the path of God. Given the use and abuse of the term since the so-called revival of Islam, Nadine Picaudou submits a very useful and authoritative historical and contextual definition of jihad;

Conceived as a permanent struggle between God's Will and most of the forces which arise as obstacles to it, it [jihad] is traditionally hierarchized by jurists in four categories: 1. Jihad of the sword, or the armed combat for God; 2. Jihad of the heart, the inner jihad which is an effort for moral and spiritual elevation; 3. Jihad of the tongue, associated with preaching; 4 . Jihad of the hand which designates most of the behaviors compatible with God's will. ${ }^{56}$

However, Nadine Picaudou suggests that "Sometimes, this hierarchy is simplified under the form of a dichotomy which would oppose the minor jihad or armed jihad to the major jihad or greater jihad, the inner struggle of the believer." ${ }^{57}$ Pursuing her analysis, Picaudou adds:

The armed jihad, which is here the main object of our reflection, is submitted to precise criteria which determine its canonical character. [...] Muslim societies of classical age,

have a part to play." In Holy Hatred, by Anissa Helie, in Reproductive Health, 2004/www.rhmjournal.org.uk, 12(23): 120-124. matters

${ }^{54}$ Assassination of the Third Caliph, Othman Ben Affan (644-655). This murder, in addition to hurting the new Umma, was to be the trigger of the "great Discord" or Fitna. It became a model to justify political assassination. Then, came the assassination of the Fourth Caliph, Ali Ibn Abi-Taleb, cousin and nephew of the Prophet. The culmination of all this was the emergence of the Khawarij. See Al-Ashmawy, 80-81.

55 Tibi, Bassam, Part II: The Context: The Politicization of Islam in the Global Age, in Islam: between Culture and Politics, Pelgrave MacMillan, 2005, 85.

56 Picaudou, Nadine, L'Islam entre religion et idéologie, $n r f$ essais, Gallimard, Paris, 2010, 212.

57 Ibid. 213. 


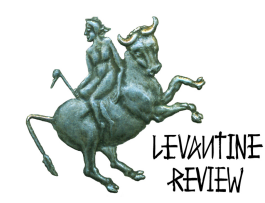

like all human societies, kept thinking of war by defining the conditions of legitimate violence and the limits to it use. Two of these deserve to be mentioned: 1 . The fact that only the Caliph, the legitimate leader of the Community, is authorized to call for jihad, and, 2. The Community obligatory character, not the individual one of offensive jihad, which is the prerogative of the Caliph's army. ${ }^{58}$

One may wonder whether this was the reason for Abu Bakr Al-Baghdadi to declare a Caliphate in the summer of 2014. One cannot help seeing the implications of such canonical rules and their distortions when the Ottoman Sultan launched his appeal for jihad at the opening of WWI when Muslim societies were under indirect or direct foreign Christian rule from the Arabian Peninsula to the Maghreb. Like the fetwas used by the Ottoman Sultan, Usama Ben Laden and his successors have used the classical jihad rhetoric to support the legality of war by turning jihad into an individual duty for all Muslims. Like the Ottoman Caliph, today's emirs, from the Mashrek to the Maghreb, have added a new element to their fanatical and oppressive propaganda: The anathema against Muslim nations and/or their leaders who collaborate with the Christian West. ${ }^{59}$

Yet, Nadine Picaudou sees a striking contrast between the Ottoman appeal of 1914, and today's various jihadist mobilizations against foreign dominations;

The new modern discourses of jihad are far away from the problématiques of legal war, they lack the casuistic subtleties of law, the result of a long historical maturation. [Instead,] they directly refer to the proselytizing of Medina. [...] In the modern age, the thematic issues of legal war are fading in front of just war. [...] To say it differently, the notion of justice is less concerned about the triumph of truth over error than about the triumph of good against evil. [...] Modern jihad manipulates the anathema and constructs an original category of apostates. [...] The criterion of apostasy is not only a renouncement of the faith but an act of treason against the Community. [...] Such is the spirit of the fetwas issued by the Ulemas of Fes, at Emir Abdel-Kader request, or that which inspires Ahmad Al-Sanusi in his treatise of jihad. ${ }^{60}$

\section{Part III \\ Political Islam: Between Faith and Ideology}

\footnotetext{
58 Ibid.

${ }^{59}$ Nadine Picaudou is probably closer to the truth when she presents "offensive jihad" as a means to expand Islam territorially as a dream of a universal empire, more than a holy war for the faith, and to think of classical jihad as a legal war more than a holy war. In L'Islam entre religion et ideologie, 215.

${ }^{60}$ Piacausou, Nadine, L'Islam entre religion et idéologie, p. 216. See also Peters, Rudolph, Jihad and Colonialism:
} 


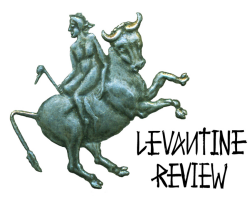

\section{Jihad in the West: 9/11/2001 and the Categorical Imperative of Understanding Jihad} As Secretary of the US Department of Homeland Security, Mr. Michael Chertoff declared: "The United States and its friends must maintain their vigilance against terrorism. But they must also combat the ideas that drive the terrorists." Quoting Mr. Jonathan Evans, Director General of the British Security Service, Mr. Chertoff added: "Although the most visible manifestation of this problem are the attacks and attempted attacks we have suffered in recent years, the root of the problem is ideological." 61 It is a matter of fact that the very ideological nature of terrorism has caused the proliferation of debates and reports regarding its very definition. Hence the pertinence of Jean-Marc Balencie's analytical approach to the "specificity of terrorism" in order to avoid the many traps of the definitional debate. Thus terrorism must simply be seen as a method of non-conventional and asymmetrical struggle or combat. In a simplified version, terrorism becomes the tool of a small number of individuals to harm the largest number of people. Ancient Chinese theoreticians put it in even clearer terms: "Kill one and terrorize one thousand."

Exploiting and manipulating today's modern media, the new modern terrorists can reach the maximum of global terror. ${ }^{62}$ Looking for the roots of terrorism, one cannot help noticing that the oldest modern roots may be found in the period of the "reign of terror" during the French Revolution under Robespierre and Danton. However, this association risks to be misguiding without the imperative distinction between two types of terrorism underlined by Jean-Marc Balencie. One group may be Clauzewitzian because of its view of terrorism as another form of armed struggle with the aim of reaching enough legitimacy to qualify as a negotiator. ${ }^{63}$ The PLO and the IRA have been successful in that category. But since the 1990's, and in particular, since September 11, 2001, a new wave of terrorists began to shake the world with new tactics and new pseudo-religious ideologies. "Fanatical

${ }^{61}$ Evans, Jonathan, Speech to the Association of Editors, "A Matter of Trust Conference", Manchester, England, 5 November 2007, in Michel Chertoff's article "The Ideology of Terrorism", 19.

62 Balencie, Jean-Marc, Les Mille et Un Visgaes du Terrorisme Contemporain, p. 19. The deterioration in US-Afghan relations became more critical in the spring of 2014 when it was revealed that the two sides were conducting secret and separate "talks" with the Talibans. See Azam Ahmed and Matthew Rosenberg, Karzai Arranged Secrets Contacts with Talibans-Allies aren't involved.Action strains US Ties-Obama Summons Top Commanders, The New York Times, February 4, 2014. P1 and 9.

63 The Israeli decision in June 1983 to attack the PLO in Lebanon was to delegitimize it as a negotiator after Ambassador Philip Habib had arranged a cease-fire between the two. Probably, Hamas's refusal of the initial Egyptian cease-fire in July 2014 may have the same significance: To remain as a legitimate interlocutor. 


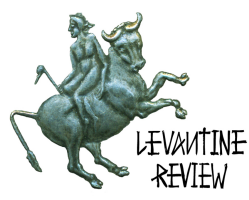

groups, impregnated with extreme radicalism, generally with religious or ethnic identity orientation, have been operating with delirious logics we can consider non-Cartesian."64

In trying to address the specificity of the emergence and evolution of Tunisian Islamism, Abdelatif Hermassi raised a series of important questions which remain vital in today's debate about the future of the place and role of Islamic law in the new constitution. ${ }^{65}$ Reflecting Bassam Tibi's modernity position, the Tunisian scholar, Hichem Djait, wrote:

In the case of Iranian political Islam, we are facing a direct control of power, [...] and this religious Islam is coming back not to reform itself, but to reform the global society and to impose itself to it. The recuperation of policies as action, and not only as thought, but the religious [...] and the integration of the religious in an eminently political process, we have here without any doubt something representing a major phenomenon the novelty of which deserves our full attention. ${ }^{66}$

In the case of Tunisia, under Bourguiba, "When independence was declared, men of religion, 'ulemas and cheikhs', imams and scholars were passed over by the nationalists. [...] Thus, those with the legitimacy that derives from theological skill were able to unite with those whose legitimacy was political in nature. They created a modernist elite existing somewhere apart from the Islamic legacy." 67 Under the Ben Ali regime, the growing threat of Ennahda-formerly called Mouvement des Tendances Islamiques-before and after the Algerian bloody civil war of the 1990s, led the Tunisian government to re-appropriate religion. For Yadh Ben-Achour, "Several authors have thought that theology and politics could not be reconciled, because divine direction and human direction are incompatible, as are revelation and philosophy." 68 Another distinguished Maghrebi scholar, Mohamed Arkoun, opening the conference on Religion and Politics, proposed two methodologies to approach the same issue. The relations between Islam and Politics could be envisaged either in a recapitulative and descriptive perspective or with the concern of thinking the various and difficult problems that such a confrontation has produced from the origin."69

64 Balencie, Jean-marc, Les Mille et Un Visage du Terrorism Contemporain, oct. 19.

${ }^{65}$ Hermassi, Abdelatif, L'Islamisme et l'Etat en Tunisie, quoted by A. Hechiche in From the Arab Spring to the Islamist Spring: Or How to Build "a democracy withour democrats?", IEEI/UNEP and in Portuguese in Politica Externa, vol 21.No.1 Jun/Jul/Ago 2012, Brazil. ${ }^{66}$ Djait, Hichem. La crise de la culture islamique, Fayard, Paris, 2004, 196.

67 Vatin, J.C, Revival in the Maghreb: Islam as an Alternative Political Language, in Islamic Resurgence in the Arab World, edite by Ali Dessouki, Praeger, 1982, 221.

68 Ben-Achour, Yadh, Normes, Foi, et Loi en particulier dans l'islam, CERES Editions, Tunis, 1993, 12.

${ }^{69}$ Arkoun, Mohamed, Religion and Politics, ACTS 15, International Conference on Sociology of Religion, Centre National de la Recherche Scientifique (CNRS) and Presses Universitaires de France, Paris, 1980, 11. 


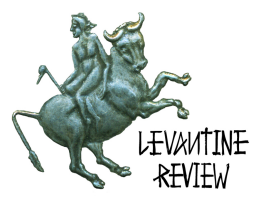

According to Ali Abderraziq, the question of the Caliphate had been a major concern in his studies and research for several years before publishing his work in 1925. For him, "caliphate" was synonymous with "Imamate."70

In the 1980s, a new generation of Islamists came of age for whom jihad is not a matter of moral rearmament, but purely of armed struggle. Their favorite form of selfpurification is martyrdom. [...] They have taken the twentieth century progression from Islam, the old religion, to Islamism, the new ideology, several steps further. Now the Arab press refers to them not just as mujahidin (holy warriors) but as jihadists. ${ }^{71}$

The seriousness of this ideological metamorphosis took more significance when Dr. Aiman Zawahiri assumed the leadership of "gihad" (Egyptian pronunciation) abroad, and when the group came under the sway of Usama Bin Laden. In that context, selective terrorism gave way to more murderous tactics, which were accompanied by the unification of personnel, tactics, and objectives, resulting in a significant radicalization of the terrorism carried out internationally. ${ }^{72}$ As examples, we have to remember the attacks against US embassies in East Africa and against US barracks in Saudi Arabia in the mid and late 1990's. This merger was facilitated by the fact that Usama Bin Laden was accepted as the Supreme Leader of Al-Qaida (The Base.) ${ }^{73}$ Bin Laden's pragmatism is another tactical skill of his. At the beginning of the Afghan adventure, he attached himself with Hikmatyar, whom the Pakistani military's Intelligence Service (ISI) wanted to install as a new ruler in Kabul. In 1996, ISI launched the Talibans as a Pakistan's stalking horse in Afghanistan because of Pakistan's fears and concerns about India's potential influence on Afghanistan. ${ }^{74}$ Moreover, the Talibans were initially financed by Saudi Arabia as a counter-weight to Hikmatyar, who sided with Saddam Hussein in 1991. To find Bin Laden in Taliban territory as a brother for

70 After defining the term "khilafa"-the replacement of somone for differen reasons-he borrows two definitions: 1. From Al-Badawi: The Imamate is the interim of the Prophet held by a person with the objective of ensuring that the religious law/shari'a be respected, and to defend the integrity of the faith. 2. From Ib-Khaldun: The Caliphate was to be leadership of gthe communiqy according to shari'a for the sake of of the community's salvation and its temporal interests, because the affairs of this world are linked with those of the hereafter...in l'Islam et les Fondements du Pouvoir, La Découverte,/cedej, Série Islam et Société, Paris, 1994, 80.

${ }^{71}$ Duran, Khalid and Abdelwahab Hechiche, Children of Abraham: An Introduction to Islam for Jews, The Globalization of Jihad, Ktav Publishing House, Inc, 2001, 73-84.

72 Ibid.

73 Bin Laden's Arabian origin gives him a psychological advantage. Jihadists believe that some of the worst people are in Saudi Arabia. However, once an Arabian is recognized as a leader, a halo attaches to him with which others cannot compete. In addition, Bin Laden has special leadership and organizational skills. See Duran and Hechiche, 75-6. 74 See Duran and Hechiche, The significant features of Bin Laden's charisma, 77 and 79. 


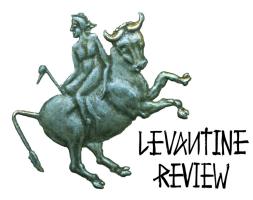

whom they were prepared to risk their lives was astonishing, all the more so since the Talibans had no connection with the international network of jihadists, such as the Muslim Brethren. This becomes all the more intriguing in June 2010, as we learn that President Karzai has been maneuvering to reach secret deals with the Talibans at the expense of US and NATO's strategic plans. ${ }^{75}$

Thus, we can see that faith and practice in Islam, as it may be in any other religion, are intimately intertwined. This is corroborated by distinguished theologians and humanists such as Cheikh Si Hamza Boubakeur and Mawlan Mohammed M. Ali who remind us that there is "no coercion in Islam, or mere beliefs forced upon a person for her/his alleged salvation."76 Among the new Maghrebi Muslim scholars, the Tunisian Yadh Ben Achour explains how

The religious mind is hostile, by tradition and impulse, to any questioning, because only the profane is questionable. The sacred requires submission, pure faith. The religious mind seeks to consolidate certitudes or to corroborate his. We know this tradition in Islam. Ahmad ben Hanbal used to say that the disputing mind is condemned to failure, and that in the heart of the disputing one, perfidy exists. ${ }^{77}$

In reconstructing the dilemma between faith and reason, Ben Achour expresses his own conviction that:

The point of view based on faith is indefensible, morally or religiously. Scientifically, because it destroys the exclusive sign of his humanity; religiously and morally, because any faith cannot-without the risk of being a mere imitation-depend on no other thing but the freedom of conscience. And the latter can be nothing else but a personal choice, in total solitude. Whether one admits or rejects E. Kant's argument according to which 'the concept of an absolutely necessary being is a pure concept of reason' [...] i.e., a simple idea the objective reality of which is far from being proven [...] or whether we accept or not the words of the prophets [...] it remains that faith cannot be resolved as a problem of collectivity. In such a case, it will no longer be faith, but a question of customs, and legislation...In its metamorphosis, it becomes political, since it is going to be grafted on customs, and laws, which makes it all the more accountable, subject to analysis as a historical phenomenon. ${ }^{78}$

75 Bob Herbert, "the Courage to Leave", The New York Times, A.19, June 12, 2010.

76 One could compare this fundamental idea with His Holiness Pope John Paul II's Encyclical "Fides et Ratio."

77 Ben Achour, Yadh, Normes, Foi et Loi, en particulier en Islam, CERES, Tunis, 1993, p. 153, quoted by A. Hechiche in What Jews Should Know About Islam and Muslims: Remembering A Common Heritage, Editions Publisud, Paris, 2004, 118.

78 Ibid. 157-158. 


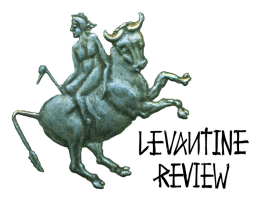

For Ibn Warraq, "Dr. Nasr Abu Zayd is a formidable scholar who has tried to bring to the study of the Koran modern literary and philosophical techniques that place texts in their historical context." Ibn Warraq gives us one of the most eloquent examples of such interpretation techniques used by Dr. Nasr Abu Zayd:

[...] The idea that, once the Koran was revealed to Mohammed, it entered history and became subject to historical and sociological laws or regularities (qawanin.) Irreversibly rent from its divine origins, the text became humanized (muta'annas,) embodying the particular cultural, political, and ideological elements of seventhcentury Arabian society: The Koran-the pivotal point of our discussion so far-is affixed religious text, from the standpoint of the literal wording, but once it has been subjected to human reason(al-'aql al-insani) it becomes a "concept" (mafhum,) which loses its fixedness as it moves and its meanings proliferate. [...] It is imperative here that we affirm that the state of the original sacred text is a metaphysical one about which we can know nothing except that which the text itself mentions and which always comes to us via a historically changing humanity. [...] From the moment of its enunciation, the divine text was shaped, and continues to be reshaped, through the operation of human reason, such that the distance now separating it from the divine is so vast as to render the text all but human. [...] In other words, the abrupt break with the divine occurring at the moment of revelation results in the total secularization of the text, which henceforth becomes a book like any other: Religious texts, in the final analysis, are nothing but linguistic texts, belonging to a specific cultural structure and produced in accord with the rules of that culture. ${ }^{79}$

\section{The Globalization of Terrorism: From Jihad to Jihadism}

Intentionally or not, in recent years, an abundant literature has demonized Islam as a religion and as a culture because of the misuse or distortion of the word "jihad," perceived and projected as "Holy War." One recent example of that is to be found in Paul Fregosi's book Jihad, in which the author tells us: "The Jihad has had a long presence on our planet, going back to the 600's, when Mohammed preached the Koran, ruled over Medina, and sent

${ }^{79}$ Nasr Abu Zayd, Naqd al-khitab al-Dini (The critique of religious discourse) Cairo, Dar alThaqafa al-Jadida, 1993, p. 93, quoted by Ibn Warraq, Leaving Islam, Apostates Speak Out, Prometheus Books, Amherst, New York, 2003, p. 34. A Gallup report released in early June 2014 revealed a pertinent information: $28 \%$ of the US population considered the Bible as the "actual word of God", while 47\% considered it as the "inspired word of God", and 21\% considered the Bible as "an ancient book of fables, legends, history and moral precepts recorded by man." See Charles M. Blow, Religious Constriction, The New York Times, June 9, 2014, A17. 


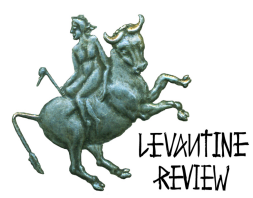

his followers to fight the pagan Arab tribes." 80 The risk of total misrepresentation or oversimplification of the term "jihad" is to be found in works like Fregosi's; "The terrorism called Jihad we know today is linked to, even if only by name, with these Muslim holy wars which began more than 1,300 years ago in Arabia, and spread during the next thirteen centuries to the Middle East, Europe, Africa, and Asia..."

Mawlana Mohammed M. Ali refutes the abusive and frequent distortions of the word jihad thanks to his detached original translation and contextual evolution of the use of the word. Jihad is derived from the verbal-root word $j h d$ (Jahd/Juhd) meaning ability, exertion or power, leading to various types of struggle: Against a visible enemy, against the devil, and against the self (Jihad An-Nafs). Mawlana Mohammed M. Ali's analysis is based on a systematic, philological, and historical review of the Quran. From his study we may retain the following points: 1 . Permission to fight was given to the Muslims when they moved to Medina, or at the earliest, on the eve of their Hijra or flight to Yathrib, which would eventually become Medina; 2 . Even in the early references to jihad, the word was used in the sense of exerting one's power and ability, without any implication of war. For instance, "And those who strive hard-Jahadu-for Us (Allah), We shall certainly guide them in Our Ways, and Allah is surely with the doers of good"82; 3. Among the latter revelations, Surat Al-Nahl (The Bees) may be mentioned because it ends with the following words: "Then surely thy Lord, with respect to those who flee after they are persecuted then struggle hard (jahadu) and are patient (sabaru,) surely thy Lord after that is Protecting, Merciful..."83

In the context of hadiths (traditions/collections of sayings and practices of the Prophet) the word jihad is not used exclusively for fighting. This seems to be supported by a saying of the Prophet "Hajj is the most excellent of all jihads." 84 In another part of Bukhari's collection of traditions, the Prophet refers to "A party of my community shall not cease to be triumphant being upholders of truth [...] and these are the men of learning (Ahla-al'Ilm.)"85 This allows Mawlana M. Ali to conclude "Thus Bukhari's view is that the triumphant party of the Prophet's community does not consist of fighters, but of men of

${ }^{80}$ Fregosi, Paul, JIHAD in the West: Muslim Conquests from the $7^{\text {th }}$ to the $12^{\text {th }}$ Centuries, Prometheus Books, Amherst, N.Y, 1998, p. 15. See also "The Diffusion of Intra-Islamic Violence and Terrosism: The Impact of the Proliferation of Salafi/Wahhabi Ideologies, http://www.gloria-center.org/2014/07/the-diffusion-ofintra-islamic-violence-andterrorism...7/18/2014

81 Ibid. 19.

82 The Holy Quran, Sura 29:69.

83 The Holy Quran, Soura 16:110.

84 Bukhari, I, 25:4, quoted by Mawlana M. Ali in Religion and Islam: A Comprehensive Discussion of the Sources, Principles, and Practices of Islam, The Ahmadyya Anjuman Isha'at Islam, (Lahore) USA, 1990, 408

85 Bukhari, (7:10) as quoted by Mawlana M. Ali, 408. 


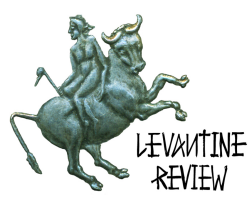

learning who disseminate the truth and are engaged in the propagation of Islam." 86 Yet, surprisingly, and perhaps paradoxically, it was among the Muslim jurists (fuqaha) that the word jihad lost its original wider significance and began to be used in its narrower sense of "qital" (fighting/killing.) As for the idea of the spread of Islam by force, it seems to be "a thing of which no trace can be found in the Quran." ${ }^{87}$ It is quite the opposite that is clearly stated in the holy book of Islam. How could the Latter declare "La-Ikraha fi-deen!" (no coercion in religion) and at the same time order proselytizing by the sword?

Mawlana Mohammad Ali's analysis and interpretation is supported by one of the finest and most authoritative studies co-authored by two distinguished scholars, Dr. Roy Mottahedeh, and Dr. Ridwan al-Sayyid. For them, "Differences about the status of Jihad are a marked feature of early Islamic law, and details about the conduct of Jihad continue to reflect historical circumstance throughout the history of Islamic law in the Middle East." 88 What is significant in this study is the negation of any "authoritatively codified Islamic law before the nineteenth century. In reviewing the available primary sources, these two scholars tried to reconstruct the earliest discussions of Jihad. They found that "The first half of the second Islamic century (which ends in 766 AD) saw the emergence of two genres of writing about jihad which either mixed history and legal thought or attempted to set down rulings for war that relied upon historical precedents. The first were the books on the military expeditions organized by the Prophet in the Medinian period, and some of those books also included the military expeditions of early caliphs." ${ }^{99}$ While books dealing specifically with jihad increased, they belonged to two categories. One category consisted of specific sections of the collections of prophetic traditions, or separate books on "the virtues of jihad." These two authors consider that The Kitab al-Jihad by 'Abdallah B. al-Mubarak alMarawazi (d. 181/797) must surely be one of the earliest examples of such individual books." 90 This interpretation is given more scholarly research authority with a long reference to the eminent scholar, Dr. Jacqueline Chabbi, according to whom there was some divergence between the Hijazi and the Syrian schools on the question of Jihad being defensive or aggressive. As a matter of fact, Professor Chabbi suggests that

It is possible to suppose that in the mid second /eighth century, the Medinian editor (or, at least, his Hanafi editor, a generation later) may have belonged to a tendency

86 Mawlan M. Ali, 408.

87 Ibid.

${ }^{88}$ Mottahedeh , Parviz Roy, and Al-Sayyid, Ridwan, The Idea of Jihad in Islam before the Crusades, in the Crusades from the Perspectives of Byzantium and the Muslim World, edited by Angeliki E. Laiou, and Roy Parviz Mottahedeh, Dunbarton Oaks Research Library and Collections, Washington, D. C, 2001, 22.

89 Ibid. 25.

90 'Abdallah b.al-Mubarak, Kitab al-Jihad, ed. N.Hammad, (Beirutm 1977) in note 7 of Roy Mottahedeh and Ridwan al-Sayyid's article, The Idea of Jihad in Islam..., 25. 


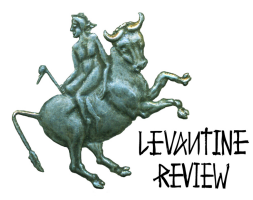

which was skeptical about warfare on the frontier; particularly with regard to the purity of the intentions of the fighters [...] there is furthermore attributed to Malik the transmission of a hadith, according to which the most scrupulous piety (ablutions, attendance at the mosque, continued observance of prayer) would be the true ribat. [...] That does indeed seem to represent a position which would effectively have been professed by Malik. [...] It may be wondered whether these traditions do not allow the supposition of a conflict of representation between traditionalists at the end of the second/eighth century. These indications could permit the fixing of the time when the ideology of jihad, professed by circles yet to be identified, began to stress the meritorious aspect of military service on the frontier, while in other circles, there was manifest opposition to this new point of view. [...] If such was the case, it could be said that this conflict would, as if symbolically, have divided those who, of quietist tendency, aspired to make mujawara (living close to the Ka'aba) from those who aspired to make ribat (dwelling on the frontier.) This latter would have professed a new type of activism. ${ }^{91}$

Jacqueline Chabbi might have found the key to the controversial definitional debate about Jihad. According to her, it was in the context of the fear of ishrak or "associationnism" as the worst potential sin against the Oneness of God that individuals had to strive to resist or even to oppose their genitors' beliefs resulting in the emergence of a Jihad. ${ }^{92}$

\section{Part IV The Regionalization of Jihad}

\section{The Case of the Maghreb}

Paradoxically, at the same time when Jihadism was moving from the Machrek to the Maghreb, scholarly researchers returned to early authoritative Maghrebi modernist political and religious leaders from the nineteenth century to the times of independence. Was it a mere coincidence that in the mid-nineteenth century, a Tunisian thinker spoke Ibn Khaldun's language? The significant statesman, Khayr al-Deen al-Tunusi, tried to pursue the same logic regarding history, faith, and relations between different civilizations. For him, there was "no reason to reject or ignore something which is correct and demonstrable simply because it comes from others, especially, if we had formerly possessed it and it had

${ }^{91}$ Chabbi, Jacqueline, "Ribat", EI 2, 8:495, quoted by Roy Mottahedeh and Ridwan al-Sayyid, in the Idea of Jihad in Islam..., 25.

${ }^{92}$ Jacqueline Chabbi deciphered the problem through her interpretation of Sura XXIX, Al"Ankabut, (The Spider) 6.8, and the change of the centrality of the confrontation between the Prophet and his adversaries in Mekka, against the Koreish, before the challenge moved to Medina from the Jews. See Chabbi, Jacqueline, Le Seigneur des Tribus; La Vie de Mahomet, Préface d'André Caquot, , Editions Noesis, 1997, 398. 


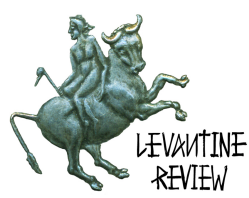

been taken from us. [...] Anyone devoted to his religion should not be deterred from imitating the commendable actions related to wordly interests..." Speaking of the French people, Khayr al-Deen added:

By ceaselessly emulating what they deem good in the work of others, they have attained the sound organization of their efforts in the world to be witnessed by all. The discriminating critic must sift out the truth of a probing examination of the thing concerned whether it be a word or a deed. If he finds it to be correct he should accept it and adopt it whether or not its originator be from among the faithful. It is not according to the man that truth is known. Rather, it is by truth that man is known. ${ }^{93}$

For students of the Maghreb of my generation, it is easy to see such a Khaldunian intellectual critical thinking passing to Habib Bourguiba, through Khayr al-Din. Beyond his "Politique des Etapes" or Policy of the Stages which led to Tunisia's independence, Bourguiba continued to educate his people through his weekly speeches to free them from all sort of inferiority complexes caused by colonialism. In addition to his courageous emancipation of women through legal codification, one of his most audacious acts was his attempt to abolish fasting during the holy month of Ramadan when, during one of those weekly speeches, he drank a glass of orange juice and declared: "My jihad is against underdevelopment." In that March 17, 1960 speech, President Habib Bourguiba declared:

There are those who prefer to fast, and they make the necessary effort to see to it that fast does not affect the output of their work. We see no objection to that [...] Nevertheless, the extra effort is undeniable. And there are others who have followed my reasoning and who have grasped my thoughts more accurately. They too have wanted to make an extra effort, but in the sense of increased productivity, and without depriving themselves of eating. ${ }^{94}$

Two months later, President Bourguiba persisted in clarifying his thoughts; "The bodily disciplines were only prescribed by the Koran in assuming a powerful Islamic State. [...] If

${ }^{93}$ Khayr al-Din al-Tunusi, The Surest Path: The Political Treatise of a Nineteeth Century Muslim Statesman, Translation from original Arabic, with introduction and notes by Leon Carl Brown, Center For Middle Eastern Studies, Harvard University Press, 1967, 75. This idea idea can be traced back to al-Ghazzali. Cf his al-Munquidh min al-dalal (p. 13): "This is the habit of those deficient in intelligence who recognize the truth according to men who profess it instead of judging men according to the truth. The genuinely intelligent man emulates the master of learned man, 'Ali, may God be pleased with him, who said:" You will not recognize the truth by means of men..", cited in I. Goldhizer, Le Livre de Mohamed Ibn Toumert, Mahdi des Almohades, Algiers, 1903.

94 François Burgat and William Dowell, "The Price of Modernity", in The Islamic Movement in North Africa, Center for Middle East Studies, University of Texas at Austin, 1993, 141. 


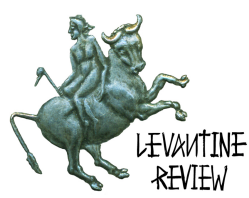

this State were in danger, political necessity would take precedence over religious necessities. The State first [...] for, without the State, religion would be in danger."95 One must bear in mind that Habib Bourguiba was a brilliant political tactician endowed with the intellectual finesse of a lawyer. His political thought about Islam in a modern State was part of the theological debate undertaken by contemporary North African ulemas who were revisiting Abu-Ishak al-Shatibi's theoretical discourse on Maqasid al-Shari'a (The objectives or legal aims of the Islamic law.) Those religious scholars were the Tunisian Muhammad alTahir Ibn-'Achur (1886-1970,) and the Moroccan, Muhammad 'Allal al-Fasi (1910-1974.)96

\section{Al-Qaedization of Algerian Islamism}

As a specialist of security matters in the Mediterranean, French Air Force General Michel Masson considered

Terrorism as a consequence and as an exacerbated manifestation of the unbalance affecting the Maghreb. [...] Terrorism in itself is not the main threat for the region. It is however a phenomenon which imposes itself on all, being capable of hitting at anytime, anywhere. [...] The scourge alone compromises stability, more particularly in the Maghreb, but today, in all the North of Africa. ${ }^{97}$

Although acts of terrorism happened in Tunisia and were attributed to MTI (Mouvement des Tendances Islamiques) before being called Ennahda, General Masson, like a few other specialists-scholars and security personnel—considers the Algerian legislative elections of December 1991, and the military decision to abolish the electoral results which favored

95 Thirteen years later, the Tunisian president went even further in questioning the coherence of the sacred text during a Conference on "Culture and the National Conscience" by referring to some contradictory verses in the Holy Book, In François Burgat and William Dowell, The Islamic Movement in North Africa, note 1, 141.

96 Yasir S. Ibrahim, An Examination of the Modern Discourse on Maqasid al-Shari'a, The Journal of the Middle East and Africa, vol.5, Number 1, January-April 2014, editred by J Peter. Pham, 41.

${ }_{97}$ Masson, Michel, Les Groupes Islamistes se réclamant d'Al-Qaida au Maghreb et au Nord de l'Afrique, Confluences Méditerranée, Hiver 2010-2011, L'Harmattan, 155. It is important to keep in mind the fluid dynamics of the Algerian groups during and after the bloody civil war of the 1990s. Fis (Fromnt Islamique du Salut) joined AIS (Armée Islamique du Salut) oftern called GIA (Groupe Armé du salut). It was by 1998 that another group, the GSPC (Groupe Salafiste Pour la Prêche et le Combat) was created under the leadership of Hassan Hattab. 


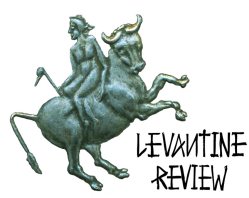

the Islamists, ${ }^{98}$ as the most critical point in the evolution of jihadism in the Maghreb, something comparable to the consequence of the Egyptian "coup" that eliminated the democratically elected President Mohamed Morsi on July 3, 2013.

The GSPC (Groupe Salafiste Pour la Predication et le Combat) will become more known through its success in recruiting Algerians who had fought in Afghanistan, already called "the Afghans" or "jihadists." It is difficult to agree with those who suggested that "US policymakers did not realize the Al-Qaida in the Maghreb (AQIM) threat until after the New York Times interviewed the AQIM leader, Abdelmalek Droukdal, who declared that the interests of the foreigners, mainly US, were under threat because they supported the Algerian regime. ${ }^{99}$ That view was to gain some credence after Secretary of Defense Robert M. Gates expressed the view that the merger of Al-Qaida with the Algerian organization and others like it "brought fresh risks." 100 The famous New York Times interview of Abdelmalek Droukdal was published on July 1, 2008. It would deserve a whole paper for its systematic analysis. Some of the main points elaborated by Mr. Droukdal's detailed answers may be summed up as follows: Jihad is justified as a war against all those who are seen as inflicting suffering on Muslims “... in Gaza, Iraq, Afghanistan, and Somalia, and other places...” Mr. Droukdal added: "Many analysts and observers are mistaken when they think that our joining was a result of secular accounts and self-interests. We are a jihad ancestral community. We rely on legitimacy (from religion) before anything else as a base of our decisions."101

When asked whether a correspondence between himself and Abu Musab Al-Zarqawi in 1994-1995 played a major role in joining Al-Qaeda was true, Mr. Droukdal replied that the correct dates were 2004-2005.

Asked about any support in Europe, Mr. Droukdal answered:

Yes, there are people who are sympathetic with us in Europe and elsewhere. [...] Most of the Muslims including those residing in Europe are against the crusade war lead by America, and they hate the Arab regimes that are working as agents and that crushed their people and sold the Palestinian cause. [...] Whoever is arrested by the European

\footnotetext{
98 Hajji, Khalifa, The Origins and Strategic Objectives of Al-Qaeda Organization in the Islamic Maghreb, Thesis, Naval Postgraduate School, Monterey, California, December 2009, 2 ${ }^{99}$ Hajji, Khalifa, The Origins and Strategic Objectives of Al-Qaeda Organization, 2. 100 Ibid.

101 An Interview With Abdelmalek Droukdal, The New York Times, July 1, 2008, 1 Http://www.nytimes.com/2008/07/01/world/africa/01transcriptdroukdal.html?pagewaned=...6/2/2014
} 


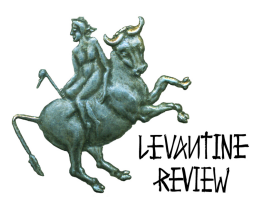

governments in Spain, France, Britain or Italy and allegedly say that they are related to our organization, all that is a lie, and deception, and injustice..$^{102}$

To another New York Times important question regarding the recruitment of fighters, Mr. Droukdal said: "The large proportion of our mujahideen comes from Algeria. And there is a considerable number of Mauritanians, Libyans, Moroccans, Tunisians, Malis and Nigerian brothers." 103

The value of the above mentioned New York Times interview helps us understand the consensus that emerged throughout the years that, more than Islamism, Jihadisn in the Maghreb is rooted in the Algerian bloody civil war of the 1990s. Peter Pham noted that already in 1989, "The Algerian government decided to legalize al-Jabha al-Islamiyya lilInqadh or Front Islamique du Salut, as an opposition party, deeming it more prudent to at least keep Islamist activities out in the open where they could be better monitored..."104 After recruiting Algerian veterans who had fought in Afghanistan, the GSPC tried to operate out of Algeria, targeting France, especially in Strasbourg. It was in December 2006, that the Number Two of Al-Qaeda, Ayman Al-Zawahiri, announced the GSPC had pledged allegiance to Al-Qaeda. In January 2007, the GSPC changed its name and became AQMI, Al-Qaeda In the Islamic Maghreb. ${ }^{105}$ Specialized literature mentions two spectacular terrorist acts in Algiers in December 2007: One against the Supreme Court, and the second against the UNCHR offices. Another major terrorist act took place on a Wednesday April 11, 2007, against the palace of the Prime Minister when I was on my way to the university. 106

In 2008, AQIM, while trying to inform public opinion of its efforts to spare innocent civilians, also made it clear that state and foreign targets were justified by "pure jihad."107 AQIM's militancy was to be seen in its double use of guerilla warfare both in the mountains of Kabylie and urban guerilla in addition to dramatic kidnappings of foreign citizens, especially those employed in the petroleum and gas industries. But church men were not spared. The novelty of AQMI's audacity was to be seen during the 2014 spectacular attack against the gas plant at Ein Ameenas in the Sahara. Overall, the tactics and the strategy

102 Ibid.

103 An Interview of Abdelmalek Droukdal, the New York Times, July 1, 2008, 3.

${ }^{104}$ Pham, J. Peter, Foreign Influences and Shifting Horizons: The Ongoing Evolution of Al Qaeda in the Islamic Maghreb, orbis, Spring 2011, 1

http://www.fpri.org/articles/2012/08/foreign-influences-and-shifting-horizons-ongoingevol...6/2/2014 , 1

105 Masson, Michel, Les Groupes Islamiques..., 137.

106 I was a Fulbright Scholar in Algeria during the academic year 2006-2007.

107 Mason, Michel, Les Groupes Islamistes, 158 


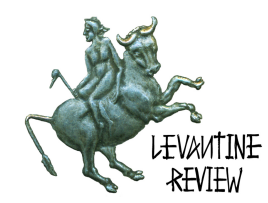

have been borrowed from the years of the war of independence under the FLN. ${ }^{108}$ The reorganization of the guerilla warfare is the strategic objective of AQMI since its affiliation with Al-Qaeda had no concern about borders. In the Maghreb, Moroccan Islamist networks are active: GICM (Groupe Islamique Combattant Marocain) tried to establish structural links with AQMI. It is the most active group to date. Another group is the Salafiyya Jihadiyya. ${ }^{109}$

What was to become crucial for AQMI was its early penetration of the Maghreb where radicalized groups would be effective propaganda vehicles for AQMI's ideology and logistics. Naturally, for the US, the September 11, 2012 attack in Benghazi which cost the lives of four US personnel including Ambassador J. Christopher Stevens, was and remains a critical blow already well exploited in domestic politics for the 2016 presidential election.

In 2010-2011, Tunisia seemed to be the only Maghreb country most spared, notwithstanding the terrorist attack against the Ghriba Synagogue in the island of Djerba. ${ }^{110}$ As for Libya, acts of terrorism began to be more frequent in 2006. The most active group was Groupe Islamique Combattant Libyen (GICL). The situation would change drastically after the fall of the Qaddafy's regime in 2011. What was to be crucial for AQMI was its early penetration of the whole region of the Maghreb, and even beyond in subSahara regions, where radicalized groups would be effective propaganda vehicles for AQMI's ideology and logistics. ${ }^{111}$

\section{Conclusion From Jihad to Ijtihad}

It is high time for Muslim religious authorities to put an end to the hijacking of Islam by Islamists and jihadists. The very fatwa of Mardin which was issued centuries ago to allow fanatical interpretations of Islam turning the religion into an ideology was condemned on April 12, 2010. One cannot but fully agree with Dr. Asghar Ali Engineer who recommends that

108 General Masson gives specific details about the structure of military regions of unequal importance, 158-159.

${ }^{109}$ According to General Masson, those groups's ideology belongs to TAKFIR which emerged in Egypt in the 1970s. It considers that society and its leaders have been astray, deviating from the right path of Islam. Therefore, we can easily imagine that it was the influence of the writings of Sayed Kutb and his particular idea of "new Jahiliyya."

110 On December 23, 2006 and January 6, 2007, there were some serious clashes in the region of the Cap Bon, and, on February 22, 2008, kidnappings of Austrian tourists took place in the South near the Algerian border.

111 One has to think of the relatively recent emergence of Boko Haram and its allies in Mali. 


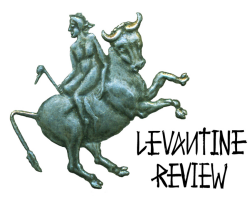

Our attention must now shift from jihad to Ijtihad, which means to strive intellectually to comprehend the problems facing the Muslim world and find their solutions in keeping with the basic principles and values enshrined in the Quran. Ijtihad was very much a living process in early Islam; its gates were shut, many scholars maintain around the sack of Baghdad by Mongol hordes in 1258. Ironically, it was half a century after that when Ibn-Tamiyya, defining his own Hanbali school of thought, issued his fatwa on jihad. Thus the gates of Ijtihad were closed, and those of Jihad flung open. ${ }^{112}$

Similar views were shared by female and male Muslim scholars who gathered in London, in the fall of 1995 at the Ibn Khaldun Organization Conference. At the same conference some Muslim female doctoral students explained how they were trying to give the Quran a femininte-if not a feminist-interpretation. ${ }^{113}$ All this was justified by the fact that Tajdid or innovation was permissible. The late and regretted Jacques Berque, using an authoritative hadith demonstrated not only the possibility, but also the necessity in Islam of understanding some form or degree of renewal in the understanding of the Quran. He went as far as to see "an old theory of modernization" in Islam, which he compared to Kant's "practical reason." 114

Irresistibly, I cannot help hearing another great mind and precursor of David Hume:

The great evils that come about between the human individuals, who inflict them upon one another because of purpose [...] opinions, and beliefs, [...] all of them derive from ignorance of the truth, I mean a privation of knowledge. For, through cognition of the truth, enmity and hatred are removed and the inflicting of harm by people on one another is abolished...115

Apparently, no sooner have we dug out some of the real roots of Jihad than young scholars have already focused on future jihad. But even this futuristic approach has compelled them to look back to the past.

112 Engineer, Asghar Ali, From Jihad to Ijtihad, a message sent to TRIALOGUE members (Trialogue@yahoo.com) April 24, 2010.

113 A promising World Congress has been announced in July 2014 to be held in Oran. Algeria in November -October 2014, for "Equality Between Muslim men and women", http://congres-international-feminin.org, mailed to me by Maghnia Bentounes.

114 Berque, Jacques, Les Efforts d'Innovation dans L'Islam Moderne, in L'Islam, La Philosophie et la Science, Les Presses de l'UNESCO, in honor of the Fifteenth Islamic Century, 1981, 74.

115 Maimonides, Moses or Moussa Ibn Maimoun, The Guide of the Perplexed, translated with an introduction and works by Sheomo Pines, with an introductory essay by Leo Strauss, University of Chicago Press, 440-1. 


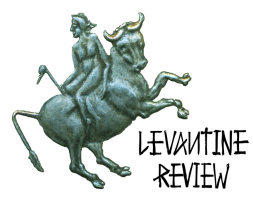

Because of its implication for international politics, the question of war and peace, and, most recently, its connection with terrorist movements [....] the concept of jihad has dramatic importance in today's world. Regardless of its ancient use, jihad as practiced by terror networks [...] is in conflict with all types of secular and human rights-based laws. But since its users-the radical organizations-and modern doctrines refer to jihad in the most historicist dimension, we are forced to investigate it historically. In other words, even if great powers used the term "jihad" in the past as a tool of war and peace, it nevertheless deserves a historical understanding since the jihadists of modern times fully adhere to its roots (or so they claim). ${ }^{116}$

A couple of final questions deserve to be addressed. If, indeed, the root of Islamism is an identity crisis between nationalism and religion, one may concur with those who see in Islamism "a language more than a doctrine, and that Islamism is a political ideology capable of competing with the great Western ideologies..."117 Some viewed "The Islam of the Muslim Brothers as a poor Islam." Others, like Michel Chodkiewicz, are bewildered by the simplistic nature of the Islamist discourse. According to François Burgat, Jean-François Clément goes even further, by considering Islamists as secularists (laïques);

In the long history of un-belief in Arab countries, contemporary Islam is truly a disconnect, because it represents the specific form of a radical novelty, atheism in the Arab countries. [...] All Islamists are sub-products of European thought, having completely abandoned Islam with regard to many questions concerning the status of politics, the possibility for man to judge the legitimacy of God's representations, which places them in complete opposition to the Ulemas of Islam. ${ }^{118}$

The second point is about the response of the West to the use of Islam as a tool of terror and jihadism, in particular after September 11, 2001, and after the so-called Jasmine Revolution of December 2010-January 2011 in Tunisia. For those who are familiar with the role of the Mediterranean and the significant asset represented by Tunisia for Operation Torch during WWII, it is rather puzzling to learn that although US policy "[t]oward the Maghreb countries is presently driven above all by security concerns," some observers are

116 Walid Phares, Future Jihad: Terrorist Strategies Against the West Palgrave Macmillan, 2005, 21.

117 Olivier Roy, L'Afghanistan, islam et modernité, Paris le Seuil (collection <<Esprit>>, 1985, quoted by François Burgat, L'Islamisme au Maghreb, Editions Khartala, 1988, note 14, 70.

118 Jean-François Clément, correspondence with François Burgat, November 1985, in L'Islamisme au Maghreb, note 17, 71. 


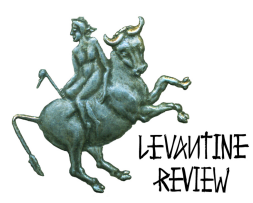

[...] berated by many (Tunisian) interlocutors for the lack of interest and support from the US for their country's transition..."119

This apparent lack of interest is in total opposition to the sudden change in US strategic assessment of North Africa as expressed by President Barak Obama at West Point Military Academy in May 2014. "For the foreseeable future, the most direct threat to America, at home and abroad, remains terrorism," noted the President, "but a strategy that involves invading every country that harbors terrorist networks is naïve and unsustainable."120 President Obama went on to lay out his "second principle":

The need for a new strategy reflects the fact that today's principal threat no longer comes from a centralized al-Qaida leadership. [...] So we have to develop a strategy that matches this diffuse threat, one that expands our reach without sending forces that stretch our military too thin or stir up local resentments. ${ }^{121}$

In such a geo-political and geo-strategic context, the US president noted that "[w]e need partners to fight terrorists alongside us..."122 Consequently, President Obama announced his "Call to Congress to support a new counter-terrorism partnership fund of \$5 billion, which will allow us to train, build capacity and facilitate partner countries on the front lines..." This time, North Africa, and the Maghreb countries in particular are explicitly designated as vital assets for the new phase of the Global War on Terrorism. The very recent spectacular arrest of the Libyan Islamist, Mr. Abu Khattala, ${ }^{123}$ could have required and justified a more direct and open American involvement in counter-terrorist operations in the Maghreb. But the unexpected situation in Iraq with the fall of Mosul and other strategic cities to ISIS seems to have drastically changed the dynamics of US policies both at home and internationally.

If the new US strategy is centered on the notion of "partnership" with regional states of the Maghreb in the case of the AQMI (Al-Qaida in the Islamic Maghreb,) one must remember how a closer geographic partnership between Europe and the Maghreb not only failed, but

119 Martina Ottawy, "American Policy in the Maghreb: Counter-terrorism is Not Enough," Viewpoints, No. 42, October 2013, Wilson Center, 1

120 President Barak Obama, Speech at the Military Academy, West Point, May 28, 2014. http://www.washingtonpost.com/politics/full-text-of-president-obama-commencementad...5/28/2014, 5-11.

121 Ibid.

122 Ibid.

123 Suspected as one of the leading actors in the September 11, 2012 attack against a compound of the US Consulate in Benghazi in which four American "diplomats", including Ambassador Christopher Stevens, were killed. 


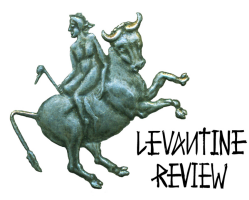

may have intensified the emergence of Salafism and Jihadism even in a moderate society like Tunisia. ${ }^{124}$

Several years before the Jasmine Revolution and the pathetic mistake of the French Defense Minister Michèle Alliot-Marie, Frederic Volpi wrote: "The analysis of the situation in North Africa illustrates that the main movers and shakers of the collaborative initiatives therethe various authoritarian regimes of the Maghreb-are in fact trying to ensure their selfpreservation at any cost."125 With references to Michael Willis and Luis Martinez, F. Volpi illustrates the fragility of the so-called "partnership" in combatting global terrorism, with two cases: Libya's u-turn after September 11, 2001, changed the country from a pariah state to "an ally in the war on terrorism and respectable regional partner." In actuality, Mu'ammar Al-Qaddafy did it after the US went to war against Saddam Hussein in March 2003. In a less dramatic fashion, the doubts that existed concerning the legitimacy of the military-backed Algerian regime and its role as a producer of regional instability at the beginning of the 1990s evaporated after September 11 to make room for a vision in which this regime is perceived to be a main bulwark against the spread of radical Islamism and terrorism regionally." 126

But, for Volpi, "The crucial point to emphasize regarding global jihadism is that such a perspective upsets traditional understanding of national-international politics and violence centered on the nation-state. It creates a situation where the targets of the global jihadists are states (and their citizens,) but the perpetrators as well as the communities they purport to defend are specifically not defined in nationalist terms." 127 The analysis was quasi prophetic given the sudden and perilous situation in Iraq in June 2014: ISIS is fighting the Maliki exclusionary and sectarian regime with the perception that the regime is exclusively recognizing the Shi'ites as citizens. Volpi's eloquent and insightful analysis sheds more light on a very complex and debatable issue even within the Muslim communities:

This mismatch between national and religious frames of reference makes it arduous to visualize and define the exact articulation of the 'new terrorism.' It also makes it difficult to understand the relationship between national-based Islamist movements and global jihadist networks. Confronted with these difficulties, many analysts have simply assumed that there is a simple causal relationship between national,

124 For a thorough documentation of terrorism in the Maghreb-country by country-, see Anneli Botha, Terrorism in the Maghreb: The Transnationalization of Domestic Terrorism, ISS Monograph Series.No.144. June 2008, Chapter 4, Tunisia, 111-123.

125 Volpi, Frederic, Introduction: Strategies for Regional Cooperation in the Mediterranean: Rethinking the Parameters of the Debate, Mediterranean Politics, vol. 11, No.2, July 2006, 130.

126 Volpi. Frederic, 130.

127 Volpi, Frederic, 126. 


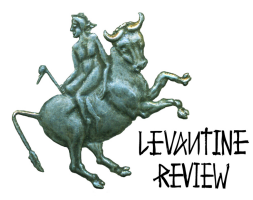

transnational and global Islamism... Current scholarship often fails to appreciate fully how often the strengthening of the global dimension of the jihadist struggle is a consequence of the weakening of the domestic strategies of political violence of national Islamist movements against the authoritarian regimes present in most of the Muslim world. ${ }^{128}$

Should we speak of "The Arab World" of "The Muslim World?" Obviously, the two are not interchangeable, especially after the "Arab Spring." Rached Ghannouchi was right to stress the difference between the two: "In North Africa, Islamization and Arabization were parallel... North Africa entered into contact with Arabness and with Islam concomitantly. There, Arabness has no cultural identity but the Islamic one, while the Machrek regions were Arabized before being Islamized." ${ }^{29}$ In 2014, the suspicion of the extension of AlQaeda in the Islamic Maghreb to Sub-Sahara Africa-Boko Haram-may not be a surprise for those who know that the establishment of Islam in Hausa land started as early as the fourteenth century. "Traditionally, Islam's law and constitution are said to have been brought by a North African cleric, Muhammad al-Maghili (d.1504). ${ }^{130}$

The so-called Jasmine Revolution that started in Tunisia brought high hopes for a genuine democratization process that opened the door for a new science: "Transitology." Long before there had been an Arab Spring, some noted that "If the democratic option sounds improbable as a response to Jihad (it is!,) think of the realist solution currently being debated-peace and stabilization through foreign invasion, expulsion, partition [...] military intervention, or simple dismemberment."131 Although similar questions were being debated in the summer of 2014 over the dramatic military advances of ISIS in Iraq, it is quite probable that the instability in Libya, combined with the recent and frequent ambushes against Tunisian soldiers near the Algerian-Tunisian border, may aggravate the regional destabilization of the whole Maghreb. ${ }^{132}$ This dangerous trend has become alarming in recent weeks when the leader of the "Zeytounia party," Adel al-'Ilmi, announced his candidacy to the presidential elections. "It is noteworthy that Adel al-'Ilmi is among those calling for polygamy, application of shari'a law, and also rejects the Tunisian

128 Ibid.

${ }^{129}$ Rached Ghannouchi, quoted by F. Burgat, L'Islamisme en face, La Découverte, Paris, $1995,51$.

130 Mervyn Jiskett, The Sword of Truth: The Life and Times of the Shehu Usman Dan Fodio, Oxford University Press, 1975, 5.

131 Barber, R. Benjamin, Jihad Vs. McWorld, Random House, 1995, 291.

132 Gall, Carlotta, Tunisia Fears attacks by citizens flocking to Jihad, The New York Times, August 6, 2014, A5. In this excellent report, Carlotta Gall refers to the work of the Soufan Group, a New-York based organization who considers that out of 12,000 jihadists in Syria, 3,000 of them are from Tunisia. 


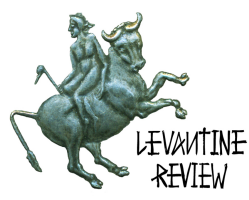

constitution which he considers to be the constitution of blasphemy, which may cause an outbreak of civil war..."133

According to Alain Rodier, "Today, the situation is favorably evolving for AQMI. Having realized that Jihad against the unfaithful (Americans, French, Spanish, British...) is a better mobilizing tool than the struggle against established powers in the Maghreb, it has become more advantageous to push the unfaithful out of the Muslim countries..."134 Finally, looking at the phenomenal development of Jihad in memory, in history, and today, its globalization in space, one cannot help stressing our skepticism regarding the "imagined truth of Salafism." Michel de Certeau reinforces this specific point: "Writing is the memory of a forgotten separation. [...] It is the endless effect of loss and debt, but it neither preserves nor restores an initial content, as this is for ever lost (forgotten) and represented only by substitutes which are inverted and transformed according to the law set up by a founding exclusion. Scriptural practice is itself a work of memory..."135 This phenomenon is part of the human condition. "The willingness of ordinary people to let themselves be guided by slogans becomes obvious at certain periods in history and is easily accounted for. However, the endurance and effectiveness of slogans over long stretches of time or the entire lifetime of civilizations are difficult, if not impossible, to calculate and to explain. This applies with particular force to civilizations of the past where any documentation, however plentiful it may seem, is fragmented in the extreme."136 Two critical thoughts from a Muslim from Saudi Arabia deserve our attention to enhance this conclusion. In 2005,

in an effort to open closed Saudi Salafi minds, King Abdullah supported dialogue with people of other religions. In my mosque, the cleric used his Friday Prayer sermon to prohibit such dialogue on grounds that it put Islam on a par with "false religions." Although this author recognized that King Abdullah was "a modernizer," he also stressed the fact that King Abdullah and his advisers "do not wish to disturb the 270year old tribal pact between the House of Saud and the founder of Wahhabism. [...] That 1744 desert treaty must now be nullified.

For this reason, Ed Husain concludes:

133 Controversial head of Islamic party announces candidacy. News article posted on 04.15.2014, htpp://www.islamopediaonline.org/news/controversial-head-tunisianislamic-party-anu...4/28/2014.

134 Rodier, Alain, Al-Qaida, Grand Gagnant des révolutions arabes?, in La Force Cachée des Révolutions Arabes, Centre de Recherche sur le Renseignement, sous la direction d'Eric Denécé, Ellipses, 2012, 499.

135 Certeau, Michel, The Writing of History, translated by Tom Conley, Columbia University Press, N.Y, 1988, 323.

136 Rosenthal, Frank, Knowledge Triumphant: The Concept of Knowledge in Medieval Islam, Leiden, E.J. Brill, 1970, 324. 


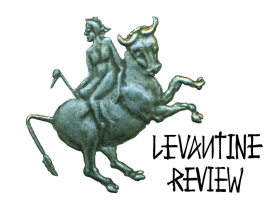

Saudi Arabia created the monster that is Salafi terrorism. It cannot now outsource the slaying of this beast to the United Nations. It must address the theological and ideological roots of the extremism at home, starting with Mecca and Medina. Reforming the home of Islam would be a giant step toward winning against extremism in this global battle of ideas. ${ }^{137}$

It is perhaps appropriate to conclude by borrowing from David Hume's empiricism; a form of humanism, as it were, in the face of human bigotry and intransigence; "it is remarkable," wrote Hume

that the principles of religion have a kind of flux and reflux in the human mind, and that men have a natural tendency to rise from idolatry to theism, and to sink again from theism to idolatry. The vulgar, that is, indeed, all mankind, a few excepted, being ignorant and uninstructed, never elevate their contemplation to the heavens, or penetrate by their disquisitions into the secret structure of vegetable or animal bodies; so as to discover a supreme mind or original providence, which bestowed order on every part of nature. They consider these admirable works in a more confined and selfish view; and finding their own happiness and misery to depend on the secret influence and unforeseen concurrence of external objects, they regard, with perpetual attention, the unknown causes, which govern all these natural events. [...] The unknown causes are still appealed to, at every emergence; and this general appearance or confused image, are the perpetual objects of human hopes and fears, wishes and apprehensions...

\footnotetext{
* Abdelwahab Hechiche is Professor of Government and International Affairs at the University of South Florida. He holds graduate and post-graduate degrees from the University of Paris, Sorbone, the Institute of Advanced international Relations of the Faculty of Law-Panthéon, and the École Pratique des Hautes Études. After being a French Fulbright Scholar from the University of Paris at Virginia Polytechnic Institute and the University of South Florida during the late 1960s, Hechiche was also a U.S. Fulbright Scholar in Algiers in 2006-2007.
}

137 Husain, Ed, Saudis Must Stop Exporting Extremism, The New York Times, Saturday August 23, 2014, p. A21. Ed Husain is an adjunct senior fellow at the Council on Foreign Relations and a senior adviser to the Tony Blair Faith Foundation. 


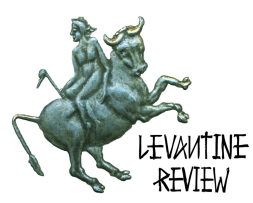

\section{Bibliography}

2011. "The Turkish Election. Result and Next Steps". Friedrich Ebert Stiftung, http://www.fesdc.org/pdf/The\%20Turkish\%20Election\%20June\%202011.pdf, Accessed 18 December 2014.

2014. "Human Rights Watch Report for Turkey 2014". Human Rights Watch Organisation, http://www.hrw.org/world-report/2014/country-chapters/turkey, Accessed 18 December 2014.

Çelik, Pekin, Aliye \& Laura, Elizabeth, Çelik 2012. "Turkey: Current and Future Political, Economic and Security Trends". Canadian Defence and Foreign Affairs Institute, http://www.cdfai.org/PDF/Turkey\%20Current\%20and\%20Future\%20Political,\%20Econ omic\%20and\%20Security\%20Trendsb.pdf, page 5, Accessed 18 December 2014.

Levitsky, Steven \& Way, A., Lucan 2010. “Competitive Authoritarianism”. Cambridge, Cambridge University Press.

Aknur, Müge 2013. "Civil-Military Relations During the AK Party Era: Major Developments and Challenges". Insight Turkey, Vol. 15 / No. 4 /2013.

Hristov, Simeon 2001. "The Crisis in Turkey". Institute For Regional and International Studies, http://www.iris-bg.org/files/Turkey.pdf, Accessed 19 December 2014.

Idiz, Semih 2014. "Erdogan's presidential rivals fight for airtime". Al Monitor, 5 August 2014, http://www.al-monitor.com/pulse/originals/2014/08/idiz-presidential-electionserdogan-fair-equal-trt-osce-akp.html\#, Accessed 18 December 2014.

Kaynar, Kars, Ayşegül 2014. "Interaction of the AKP With the Constitutional State in Turkey: AKP's Political Justice”. Doctoral Thesis, Department of Political Science and Public Administration, Middle East Technical University, http://etd.lib.metu.edu.tr/upload/12617635/index.pdf, pp.175, Accessed 19 December 2014.

Sayarı,Sabri 2011. "Clientalism And Patronage in Turkish Politics and Society". In Toprak, Binnaz and Birtek, Faruk, (eds.) "The Post Modern Abyss and the New Politics of Islam: Assabiyah Revisited Essays in Honor of Şerif Mardin." Istanbul Bilgi University Press, Istanbul, http://research.sabanciuniv.edu/16988/1/Mardin_Volume.pdf, pp.13, Accessed 19 December 2014.

Somer, Murat 2007. "Moderate Islam and Secularist Opposition in Turkey: Implications for the World, Muslims and Secular Democracy". Third World Quarterly, Vol. 28, No. 7, 2007.

Öniş, Ziya 2013. "Sharing Power: Turkey's Democratization Challenge in the Age of the AKP Hegemony." Insight Turkey, Vol. 15 / No. 2 /2013. 


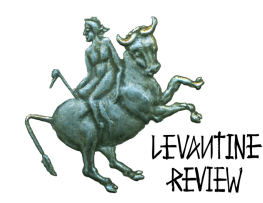

Rabasa, M., Angel (et al.) 2004. "The Muslim World After 9/11.” Rand Corporation, http://www.rand.org/content/dam/rand/pubs/monographs/2004/RAND_MG246.pdf, page 22, Accessed 18 December 2014.

Toker, Cem 2014. "Elections In Turkey: Fair Or Fraud-Ridden?" Turkish Policy Quarterly, Winter 2014, http://www.turkishpolicy.com/dosyalar/files/vol_12-no_4-toker.pdf, Accessed 18 December 2014.

Yeldan, Erinç 2002. "Behind the 2000/2001 Turkish Crisis: Stability, Credibility and Governance, for Whom?" Bilkent University, http://yeldane.bilkent.edu.tr/Chennai_Yeldan2002.pdf, Accessed 19 December 2014.

"The Constitution of the Republic of Turkey."

http://www.hri.org/docs/turkey/con2d.html. Accessed 18 December 2014.

Yavuz, M., Hakan 2003. "Islamic Political Identity in Turkey.” Oxford University Press, Oxford.

Yılmaz, Hakan. 'Conservatism in Turkey". http://www.esiweb.org/pdf/esi_turkey_tpq_vol7_no1_HakanYilmaz.pdf. Accessed 19 December 2014. 